\title{
Electrical, Thermal, and Mechanical Properties of Mg-TiB 2 Nanocomposites Produced by Spark Plasma Sintering
}

\author{
Kıvılcım Plazma Sinterleme Yöntemiyle Üretilen Mg-TiB 2 Nanokompozitlerin \\ Elektriksel, Isıl ve Mekanik Özellikleri
}

Ege Anıl DİLER ${ }^{1}$

${ }^{1}$ Ege University, Department of Mechanical Engineering, 35040, Izmir, Turkey

\begin{abstract}
Monolithic magnesium was reinforced with nano- $\mathrm{TiB}_{2}$ particles to produce $\mathrm{Mg}$ - $\mathrm{TiB}_{2}$ nanocomposites, and the effects of nano$\mathrm{TiB}_{2}$ particles on the electrical, thermal, and mechanical properties of $\mathrm{Mg}$ matrix nanocomposites were studied. Monolithic $\mathrm{Mg}$ and $\mathrm{Mg}-\mathrm{TiB}_{2}$ nanocomposites were manufactured using spark plasma sintering process. Both analytical and experimental findings revealed that the electrical and thermal conductivities of $\mathrm{Mg}_{-} \mathrm{TiB}_{2}$ nanocomposites were lower than those of monolithic $\mathrm{Mg}$ and decreased as the amount of nano- $\mathrm{TiB}_{2}$ particles increased. The electrical and thermal conductivities of $\mathrm{Mg}-\mathrm{TiB}_{2}$ nanocomposites decreased at a higher rate for a higher weight fraction of nano- $\mathrm{TiB}_{2}$ particles. The experimental electrical and thermal conductivities of $\mathrm{Mg}^{-\mathrm{TiB}_{2}}$ nanocomposites at a certain amount of nano- $\mathrm{TiB}_{2}$ particles was measured at lower values than those obtained by analytical calculations. The compressive strength of $\mathrm{Mg}-\mathrm{TiB}_{2}$ nanocomposites was higher than that of monolithic $\mathrm{Mg}$ and improved as the weight fraction of nano- $\mathrm{TiB}_{2}$ particles increased; however, a high amount of nano- $\mathrm{TiB}_{2}$ particles resulted in a decrease in compressive strength. The compressive strength of $\mathrm{Mg}-\mathrm{TiB}_{2}$ nanocomposite with $1.5 \mathrm{wt} . \%$ nano- $\mathrm{TiB}_{2}$ particles improved by $34 \%$; on the other hand, its failure strain decreased by $12 \%$ compared to monolithic $\mathrm{Mg}$. Keywords: Electrical conductivity, thermal conductivity, spark plasma sintering, nano- $\mathrm{TiB}_{2}$, compressive strength.
\end{abstract}

Öz

Monolitik magnezyum, nano- $\mathrm{TiB}_{2}$ partikülleri ile takviyelendirilerek $\mathrm{Mg}-\mathrm{TiB}_{2}$ nanokompozitleri üretilmiş ve nano- $\mathrm{TiB}_{2}$ partiküllerinin $\mathrm{Mg}$ matrisli nanokompozitlerin elektriksel, 1sıl ve mekanik özellikleri üzerindeki etkileri incelenmiştir. Monolitik Mg ve $\mathrm{Mg}-\mathrm{TiB}_{2}$ nanokompozitler kıvılcım plazma sinterleme yöntemi ile üretilmiştir. Hem analitik hem de deneysel sonuçlar, $\mathrm{Mg}-\mathrm{TiB}_{2}$ nanokompozitlerin elektriksel ve 1 s1l iletkenliklerinin monolitik Mg'den daha düşük olduğunu ve nano-TiB 2 partiküllerinin miktarı arttıkça elektriksel ve ısıl iletkenliklerinin azaldığını ortaya koymuştur. $\mathrm{Mg}-\mathrm{TiB}_{2}$ nanokompozitlerin deneysel olarak bulunan elektriksel ve 1 sıl iletkenliklerinin, daha yüksek nano-TiB 2 partikül miktarlarında daha yüksek oranda düştüğü saptanmıştır. Belirli miktarda nano- $\mathrm{TiB}_{2}$ partikül içeren $\mathrm{Mg}-\mathrm{TiB}_{2}$ nanokompozitlerin deneysel elektriksel ve 1 sıl iletkenlikleri, analitik hesaplamalar ile elde edilen sonuçlardan daha düşük değerlerde bulunmuştur. $\mathrm{Mg}_{-} \mathrm{TiB}_{2}$ nanokompozitlerin basma dayanımları monolitik Mg'den daha yüksek olmakla birlikte, nano-TiB 2 partikül miktarı arttıkça basma dayanımı artmış, ancak yüksek miktarda nano- $\mathrm{TiB}_{2}$ partiküllerin kullanılması basma dayanımında azalmaya neden olmuştur. Monolitik Mg ile karşılaştırıldığında, ağırlıkça \%1,5 nano-TiB 2 partikül içeren $\mathrm{Mg}$ - $\mathrm{TiB}_{2}$ nanokompozitinin basma dayanımı \%34 artış gösterirken, hasar gerinimi ise \%12 azalmıştır.

Anahtar Kelimeler: Elektriksel iletkenlik, 1s1l iletkenlik, kıvılcım plazma sinterleme, nano-TiB2, basma dayanımı.

\section{INTRODUCTION}

Nano-particle reinforced metal matrix composites, also known as metal matrix nano-composites (MMNCs), have superior properties over metal matrix composites reinforced with micro-sized particles because nano-particles are much more efficient in the mechanisms that increase the strength of the composite materials [1]. Over the halfcentury, MMNCs have become more favored in a variety of applications such as aerospace due to higher specific strength/stiffness, higher operating temperatures, and improved wear resistance compared to monolithic metals [2]. For instance, it is desirable for aircraft brakes to be made of MMNCs with high thermal conductivity and improved wear resistance combined with high strength [3].

Because of its low density and high thermal and electrical conductivities, magnesium is increasingly replacing aluminum and steel in the automotive and aerospace applications, as well as plastic in the electronic industry [4]. $\mathrm{Mg}$ has been used in a variety of automotive components, including transfer cases, radiator supports, instrument panel beams, and steering components [5]. $\mathrm{Mg}$ is the structural metal with the lowest density but it has weak strength. Ceramic-based materials are added to magnesium to overcome this drawback and improve mechanical properties such as hardness and wear resistance. Since nano-particles are more effective at strengthening, nanoparticle reinforced $\mathrm{Mg}$ matrix composites may be favored for the production of structural components. Heat sinks 
are used to dissipate the heat created by electronic components while they are operating and to protect them from damage. For this reason, optimal heat sink materials should have superior thermal conductivity to disperse heat generated by electronic components, as well as high strength and good abrasive wear behavior to protect the electronic components. Furthermore, the heat sink materials must have an appropriate coefficient of thermal expansion to avoid significant thermal stresses generated at the interface between the heat sink and the electronic component. $\mathrm{Mg}$ has a relatively high thermal conductivity and low density, making it a popular material for heat sinks. However, because the coefficient of thermal expansion (CTE) of $\mathrm{Mg}$ is so high in comparison to that of semi-conductor materials, thermal stress and strain may occur at the interface between them. $\mathrm{Mg}$ matrix composites allow for the tailoring of $\mathrm{Mg}$ characteristics by adding a ceramicbased reinforcement phase to fulfill the requirement for low CTE in thermal control [6]. For all of these reasons, $\mathrm{Mg}$ matrix composites reinforced with $\mathrm{TiB}_{2}$ particles may be a promising material for the fabrication of components in a variety of applications, including automotive and electronics.

The thermal conductivity of MMCs is influenced by several factors including thermal conductivity of the constituent materials, the uniformity of the distribution of the reinforcements, the degree of porosity, and the properties of the interfacial bond between the matrix and reinforcement particles. Rudajevová and Lukáč [7] investigated the thermal conductivity of Mg-based composites and stated that the thermal conductivity of $\mathrm{Mg}-\mathrm{SiC}$ composites decreased with an increase in the weight fraction of $\mathrm{SiC}$ particles. However, it should be noted that the studies related to thermal conductivity of particle-reinforced $\mathrm{Mg}$ matrix composites, especially those reinforced with nano-particles, have been very limited.

The key advantage of MMNCs is the improved tensile strength combined with high fracture toughness. However, some difficulties may be encountered in the production of MMNCs because nano-particles are more likely to agglomerate due to their large surface area. In particular, the agglomeration and wettability of nanoreinforcement particles are the biggest challenges in liquid-state production methods [8]. Compared to liquid-state production methods, pre-processes such as mechanical alloying and ball milling in solid-state production methods allow for a more uniform distribution of nano-particles in the microstructure. On the other hand, long processing (sintering, etc.) times during production with solid-state production methods such as hot pressing and extrusion, cause matrix grain growth, which is one of the most important problems encountered on the properties of MMNCs. Preventing or minimizing grain coarsening is possible by controlling parameters such as heating rate during pressing and sintering. Compared to conventional solid-state methods such as cold pressing+sintering and hot pressing (HP), materials with almost full density can be produced by reducing the porosity by means of spark plasma sintering (SPS) process, resulting in an enhancement in the mechanical properties of the materials [9-11]. SPS method has been used over the past years in the production of many materials including metals, ceramics (carbides, oxides, borides, and nitrides) and composites for obtaining fully dense materials [12]. SPS and HP methods are similar to each other but there is a difference between the heating mechanisms of these two methods. The heat in HP method is obtained by means of radiation principle, while the heat in SPS method is supplied by the Joule heating produced by the electrical spark discharge phenomenon (a pulsed direct electric current). Therefore, grain growth during the conventional sintering, as in HP methods, is a significant problem in the improvement of MMNCs, whereas in contrast to HP method, sintering in the SPS method can be conducted at lower processing times and higher heating rates, resulting in a submicron or nano-sized structure that enhances the mechanical properties of the materials.

Aluminum, magnesium, titanium, copper, and their alloys are the most common metals used in the production of materials using the SPS method [12]. Mg is the lightest among these metals. Furthermore, the specific strength of $\mathrm{Mg}$ is comparable to that of aluminum. Some researchers therefore focused on the mechanical properties of $\mathrm{Mg}$-based materials produced by the SPS method. Muhammad et al. [13] investigated the influence of the SPS method on the microstructure and mechanical properties of $\mathrm{Mg}$ manufactured at different sintering temperatures under $60 \mathrm{MPa}$ for a holding time of $5 \mathrm{~min}$ in vacuum. They observed that there was no significant increase in grain growth and suggested that the mechanical properties of $\mathrm{Mg}$ were enhanced by the SPS method. Mondet et al. [14] consolidated the AZ91 magnesium alloy using the SPS at various sintering temperatures $\left(310-500{ }^{\circ} \mathrm{C}\right)$ for a holding time of $5 \mathrm{~min}$. They compared the yield (YCS) and ultimate (UCS) compressive strengths of AZ magnesium alloys manufactured by the SPS method and casting method followed T6 heat treatment and found that the UCS and the YCS of AZ magnesium alloy produced by the SPS method were higher by $16 \%$ and $49 \%$, respectively, than those manufactured by casting method.

Even if the SPS method improves the mechanical properties of $\mathrm{Mg}$ more than other production methods, $\mathrm{Mg}$ has some limitations due to low strength and modulus at high temperatures and poor wear resistance. The mechanical properties of $\mathrm{Mg}$ can be enhanced by reinforcing nano- and micro-sized ceramic particles such as $\mathrm{SiC}, \mathrm{Al}_{2} \mathrm{O}_{3}, \mathrm{TiC}$, and $\mathrm{B}_{4} \mathrm{C}$ [15]. Several studies have been conducted to investigate and compare the mechanical properties of both monolithic and particlereinforced metal matrix composites. For example, 
Muhammad et al. [16] produced SiC particle reinforced $\mathrm{Mg}$ matrix composite using SPS method with a pressure of $60 \mathrm{MPa}$ at sintering temperatures (455-585 ${ }^{\circ} \mathrm{C}$ ) at a sintering time of $5 \mathrm{~min}$. As expected, the $\mathrm{Mg}$ $\mathrm{SiC}$ composite had better mechanical properties than the monolithic $\mathrm{Mg}$ and AZ31 Mg alloy. Garbiec [17] studied $\mathrm{Mg}-\mathrm{Al}_{2} \mathrm{O}_{3}(5,10,15,20$, and $30 \mathrm{vol} . \%)$ composites manufactured by the SPS method under a pressure of $50 \mathrm{MPa}$ and at a temperature of $550^{\circ} \mathrm{C}$ for 5 min. It was reported that a near-full densification $(99.41 \%)$ was achieved for $\mathrm{Mg}-\mathrm{Al}_{2} \mathrm{O}_{3}$ composites with 5wt.\% $\mathrm{Al}_{2} \mathrm{O}_{3}$ and that, compared to unreinforced $\mathrm{Mg}$, the hardness and compressive strength of $\mathrm{Mg}-\mathrm{Al}_{2} \mathrm{O}_{3}$ composites were improved for $\mathrm{Mg}-\mathrm{Al}_{2} \mathrm{O}_{3}$ (up to 30wt.\%). Some researchers compared the SPS method with the other efficient solid-state production methods, such as microwave sintering, to investigate the effects of production method on the mechanical properties of $\mathrm{Mg}$ matrix composites. For instance, Gasali et al. [18] produced $\mathrm{Mg}-5 \mathrm{wt} . \% \mathrm{~B}_{4} \mathrm{C}$ composites at $500{ }^{\circ} \mathrm{C}$ and 670 ${ }^{\circ} \mathrm{C}$ using SPS and microwave sintering, respectively. They suggested that $\mathrm{Mg}-\mathrm{B}_{4} \mathrm{C}$ composites produced using the SPS method had higher density, hardness, and bending strength than $\mathrm{Mg}-\mathrm{B}_{4} \mathrm{C}$ composites manufactured using the microwave sintering method.

The studies mentioned above focused on microparticle-reinforced Mg-based composites. Whereas nano-sized particles are more effective in enhancing the mechanical properties of $\mathrm{Mg}$-based composites. For instance, Zhang et al. [19] reinforced $\mathrm{Mg}$ powders with nano-SiC particles $(0.3,0.6,1.2$, and 2.4 wt. $\%)$ using the SPS process and achieved $80 \%$ and $73 \%$ increase in tensile and compressive yield strengths of $\mathrm{Mg}$-SiC (1.2wt.\%), respectively, as compared to monolithic $\mathrm{Mg}$. However, there are very few studies investigating the effect of nano-particles on the mechanical properties of $\mathrm{Mg}$ matrix composites manufactured by the SPS method.

In addition to $\mathrm{SiC}, \mathrm{Al}_{2} \mathrm{O}_{3}, \mathrm{TiC}$, and $\mathrm{B}_{4} \mathrm{C}$ [20], $\mathrm{TiB}_{2}$ is another ceramic-based particle used as a reinforcement in Mg-based metal matrix composites due to high hardness, elastic modulus, strength to density ratio, and wear resistance [21]. Rather than using the SPS process, the researchers studied $\mathrm{Mg}-\mathrm{TiB}_{2}$ composites which were produced through solid-state methods such as cold-pressing+sintering and hot pressing [4,22,23]. In these studies, micro-sized $\mathrm{TiB}_{2}$ reinforcement particles were used, and unfortunately, electrical, thermal, and some mechanical (with the exception of mechanical properties such as hardness and wear resistance) properties were not investigated. It should be noted that no study has been found in the literature that investigates the electrical, thermal, and mechanical properties of $\mathrm{Mg}$ matrix composites reinforced with nano-sized $\mathrm{TiB}_{2}$ particles produced using solid-state production methods in the same study.

For all of these reasons stated above, $\mathrm{Mg}$ matrix composites reinforced with nano- $\mathrm{TiB}_{2}$ particles were produced using the SPS method, and the electrical, thermal, and mechanical properties of monolithic $\mathrm{Mg}$ and $\mathrm{Mg}-\mathrm{TiB}_{2}$ composites were analytically and experimentally investigated in this study.

\section{MATERIALS AND METHODS}

Commercially pure magnesium powders $(47 \pm 8 \mu \mathrm{m}$, G.C.M.I.T. Co. Ltd.) and nano- $\mathrm{TiB}_{2}$ particles $(50 \mathrm{~nm}$, S.E.M. Co. Ltd.) were used to produce $\mathrm{Mg}_{-}-\mathrm{TiB}_{2}$ nanocomposites (Figure 1). Nominal chemical composition of $\mathrm{Mg}$ powders is shown in Table 1. Figure 2 shows the steps in the production of monolithic $\mathrm{Mg}$ and $\mathrm{Mg}-\mathrm{TiB}_{2}$ nanocomposites.
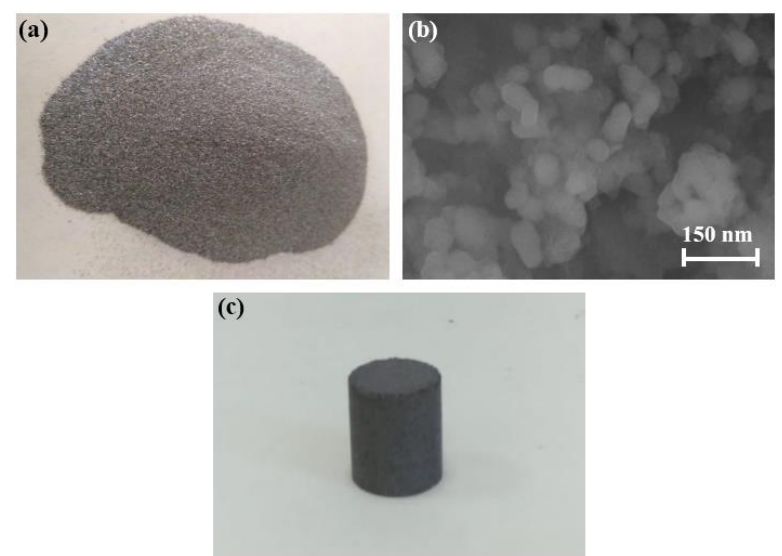

Figure 1. (a) $\mathrm{Mg}$ powders, (b) nano- $\mathrm{TiB}_{2}$ particles, and (c) $\mathrm{Mg}-\mathrm{TiB}_{2}$ nanocomposite specimen

Table 1. Nominal chemical composition of commercially pure $(99.1 \%)$ magnesium powders

\begin{tabular}{lccccccccccc}
\hline & $\mathrm{Al}$ & $\mathrm{Ca}$ & $\mathrm{Cu}$ & $\mathrm{Fe}$ & $\mathrm{Mn}$ & $\mathrm{Na}$ & $\mathrm{Ni}$ & $\mathrm{Si}$ & $\mathrm{Ti}$ & $\mathrm{Zn}$ & $\mathrm{Mg}$ \\
\hline $\begin{array}{l}\text { Weight } \\
(\%)\end{array}$ & 0.1408 & 0.0839 & 0.1541 & 0.1224 & 0.1297 & 0.0031 & 0.1056 & 0.0862 & 0.0025 & 0.0577 & Bal. \\
\hline
\end{tabular}




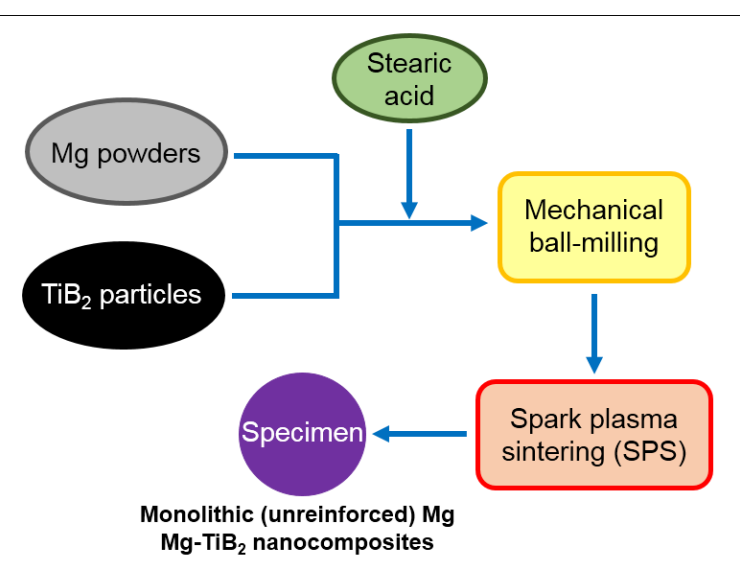

Figure 2. Production of monolithic $\mathrm{Mg}$ and $\mathrm{Mg}-\mathrm{TiB}_{2}$ nanocomposite specimens

Certain amounts $(0.5,1,1.5$, and 2 wt. $\%)$ of nano-TiB 2 particles were added to $\mathrm{Mg}$ powders. To achieve uniform distribution of nano- $\mathrm{TiB}_{2}$ particles in $\mathrm{Mg}$ matrix, a mechanical ball milling process was carried out using a planetary ball milling machine (DECO, PBM-V-2L-B). Prior to this process, stearic acid (2 wt.\%), as a process control agent to prevent excessive cold-welding of powders, was added to the mixture of $\mathrm{Mg}$ powders/nano- $\mathrm{TiB}_{2}$ particles. The mechanical ball milling process was performed with a ball-to-powdermixture weight ratio of 30:1 at a rotational speed of 300 $\mathrm{rpm}$ for an active milling time of $24 \mathrm{~h}$ under argon atmosphere. It should be noted that the mechanical milling process was interrupted every $45 \mathrm{~min}$ in order to prevent excessive heating of the powders.

Pre-pressing was applied to milled powders at a pressure of $15 \mathrm{MPa}$ prior to the application of the main consolidation method. Spark plasma sintering (SPS) process was then applied to the pre-pressed powders (Figure 3). Due to the high amount, large size, and nonuniform distribution of voids between the powders, loose powders poured into the die cavity cause the current to not be homogeneously distributed in the powder specimen during the SPS process, resulting in a temperature gradient during discharging. Inhomogeneous temperature distribution can also cause local variations in Joule heating [24]. However, in a compact structure formed by pre-pressing, this can make discharging and Joule heating more efficient during the SPS process because the contact points and areas of powders with each other would increase [25]. For all of these reasons, pre-pressing process was applied to the powders in this study to make them more compact and therefore perform better in the SPS process. The SPS method was used to produce cylindrical specimens with a diameter of $14 \mathrm{~mm}$ and a height of about $27 \mathrm{~mm}$ at a temperature of $575^{\circ} \mathrm{C}$ and a heating rate of $50^{\circ} \mathrm{C} / \mathrm{min}$ for a holding time of $5 \mathrm{~min}$ at a compaction pressure of $50 \mathrm{MPa}$ in a vacuum of $5 \times 10^{-2} \mathrm{mbar}$ (FCT, HP D). The pulsed current was set as 12:2 in on/off mode. Graphite die was used in the SPS process.

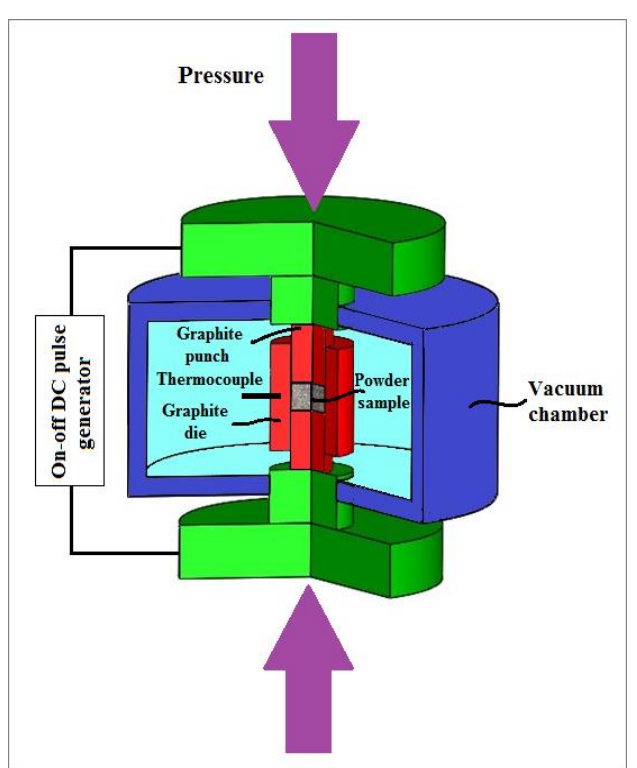

Figure 3. Configuration of the spark plasma sintering system

The thermal conductivities $(\lambda, \mathrm{W} /(\mathrm{m} \cdot \mathrm{K}))$ of monolithic $\mathrm{Mg}$ and $\mathrm{Mg}-\mathrm{TiB}_{2}$ nanocomposites were calculated as given below:

$\lambda=\alpha \cdot \rho \cdot C_{p}$

where $\alpha$ is the thermal diffusivity, $\rho$ is the density, and $C_{p}$ is the specific heat capacity. The thermal diffusivity $(\alpha)$ of the specimens was measured using a laser flash apparatus (Netzsch, LFA475). Any differences in porosity and particle clustering in particle-reinforced metal matrix composites may be presented within the cross-section of the specimen, which can have a significant effect on the accuracy of the electrical conductivity measurements. For this reason, in this study, to determine the electrical conductivity of the specimens, measurements were obtained from three separate regions (the base (surface), the cross-section in the middle of the height, and cross-section at a distance of $6 \mathrm{~mm}$ from the surface of the specimen) in a specimen, and from each of these regions from 5 different areas, for a total of 15 different regions. The average of these fifteen measurement values was taken for each specimen to determine its electrical conductivity.

In addition to thermal conductivity, the electrical conductivity (Sigmascope, SMP10 HF) of the specimens was measured at room temperature. Due to the specifications (limitations) of the thermal conductivity measurement device, the diameters of the samples were reduced to $10 \mathrm{~mm}$ and then cut from the surface to the middle of the height of the specimen (parallel to the cross-section of cylindrical specimen) to produce three pieces (specimens) with a thickness of 4 $\mathrm{mm}$. The thermal conductivity of each sample was calculated from the average of three measurement values. 
The densities $(\rho)$ of monolithic $\mathrm{Mg}$ and $\mathrm{Mg}-\mathrm{TiB}_{2}$ nanocomposites were determined using Archimedes' principle and a high accuracy balancer $( \pm 0.01 \mathrm{mg})$ (Precisa, XB220A-SCS). In addition to the measurement of experimental density $(\rho)$, the theoretical density $\left(\rho_{t h}\right)$ of the $\mathrm{Mg}-\mathrm{TiB}_{2}$ nanocomposites was calculated using the rule of mixtures (ROM) given in Equation (2) to determine the degree of porosity of the samples:

$\rho_{t h}=V_{m} \cdot \rho_{m}+V_{r} \cdot \rho_{r}$

where $V_{m}$ and $V_{r}$ are the volume fractions of the matrix and the reinforcement particles, respectively, and $\rho_{m}$ and $\rho_{r}$ are the densities of the matrix and the reinforcement particle, respectively. Theoretical densities of $\mathrm{Mg}$ and $\mathrm{TiB}_{2}$ were $1.74 \mathrm{~g} / \mathrm{cm}^{3}$ and 4.5 $\mathrm{g} / \mathrm{cm}^{3}$, respectively.

After determining the experimental $(\rho)$ and theoretical densities $\left(\rho_{t h}\right)$, the porosity in the specimens was calculated by using the following equation:

Porosity $(\%)=\frac{\rho_{t h}-\rho}{\rho_{t h}} \times 100$

A compression test was performed on monolithic $\mathrm{Mg}$ and $\mathrm{Mg}_{-} \mathrm{TiB}_{2}$ nanocomposites to determine compressive yield strength, ultimate compressive strength, and failure strain (Shimadzu, AG-IS-100 kN). The initial dimensions of the specimens (14 $\mathrm{mm}$ in diameter and $27 \mathrm{~mm}$ in height) were then reduced by machining to $13 \mathrm{~mm}$ in diameter and $25 \mathrm{~mm}$ in order to perform compression tests at room temperature at a strain rate of $0.005 \mathrm{~min}^{-1}$ according to the ASTM E9 standard.

\section{RESULTS AND DISCUSSION}

Figure 4 shows the distributions of nano- $\mathrm{TiB}_{2}$ particles in the matrix of $\mathrm{Mg}-\mathrm{TiB}_{2}$ nanocomposites. While nano$\mathrm{TiB}_{2}$ particles were uniformly distributed in the matrix of $\mathrm{Mg}-\mathrm{TiB}_{2}$ nanocomposites with low weight fractions of nano- $\mathrm{TiB}_{2}$ particles (Figure 4(a) and (b)), agglomeration and clustering of nano- $\mathrm{TiB}_{2}$ particles occurred in $\mathrm{Mg}_{-} \mathrm{TiB}_{2}$ nanocomposites with relatively high weight fractions of nano- $\mathrm{TiB}_{2}$ particles (Figure 4(c) and (d)). As the weight fraction of nano- $\mathrm{TiB}_{2}$ particles increased, the number and size of clusters of nano- $\mathrm{TiB}_{2}$ particles in the matrix of $\mathrm{Mg}-\mathrm{TiB}_{2}$ nanocomposites increased, as can be seen in Figure 4(c) and (d). The agglomeration and clustering of reinforcement particles have a negative influence on the electrical, thermal, and mechanical properties of particle-reinforced metal matrix composites, and their effects will be discussed in the following sections.
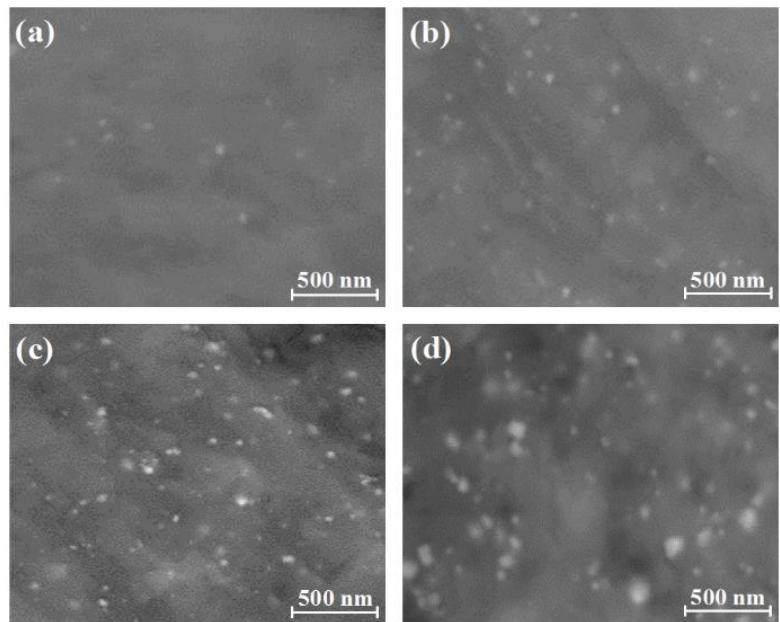

Figure 4. SEM images of $\mathrm{Mg}-\mathrm{TiB}_{2}$ nanocomposites with (a) 0.5 wt.\%, (b) 1 wt. $\%$, (c) 1.5 wt. $\%$, and (d) 2 wt. $\%$ nano- $\mathrm{TiB}_{2}$ particles

The XRD analyzes of monolithic $\mathrm{Mg}$ and $\mathrm{Mg}-\mathrm{TiB}_{2}$ nanocomposite having $1.5 \mathrm{wt} . \%$ of nano- $\mathrm{TiB}_{2}$ particles are shown in Figure 5. Magnesium has a strong affinity for oxygen. As seen in Figure 5, $\mathrm{MgO}$ was detected in the XRD analysis. $\mathrm{MgO}$ may have been formed during the production processes due to the process temperature and time. However, it should be stated that the peak of $\mathrm{MgO}$ was hardly detected, indicating that oxidation was very limited due to the processes being carried out in protective atmospheres. $\mathrm{MgO}$ was barely observable in as-received (initial) $\mathrm{Mg}$ powders in the XRD analysis when compared to those obtained after production processes (mechanical milling and SPS); however, its level after mechanical milling was probably higher because its peak was detectable more easily. It can be attributed to the long process time $(24 \mathrm{~h})$ of the mechanical milling process because $80 \%$ of the energy supplied during this process is converted into heat [26], suggesting that the possibility of $\mathrm{MgO}$ formation was high even though the process was carried out in an argon atmosphere. According to XRD analyzes, the heights of the peaks of $\mathrm{MgO}$ before (in other words after mechanical milling) and after SPS were very close (even equal) to one other. It can be attributed to the substantially shorter processing time ( $5 \mathrm{~min}$ ) of the SPS process, despite the fact that the temperature was high in this process. It should also be noted that the levels of $\mathrm{MgO}$ in both monolithic and $\mathrm{Mg}-\mathrm{TiB}_{2}$ nanocomposite were very similar. 


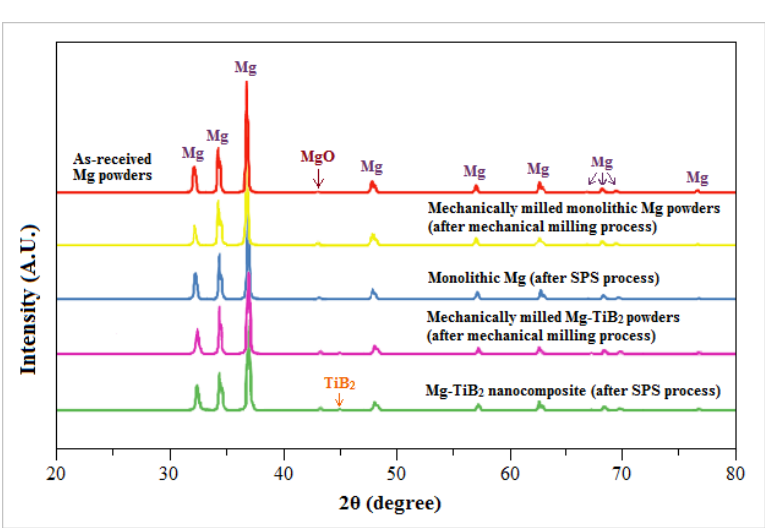

Figure 5. XRD analysis of as-received, mechanicallymilled, and SPS-sintered monolithic Mg powders, and mechanically-milled and SPS-sintered $\mathrm{Mg}-\mathrm{TiB}_{2}$ nanocomposite with $1.5 \mathrm{wt} . \%$ of $\mathrm{TiB}_{2}$ nano-particles

\subsection{Thermal Conductivity}

Figure 6 shows the thermal conductivity (experimental) of monolithic $\mathrm{Mg}$ and $\mathrm{Mg}-\mathrm{TiB}_{2}$ nanocomposites. The thermal conductivities of $\mathrm{Mg}-\mathrm{TiB}_{2}$ nanocomposites were poorer than that of monolithic $\mathrm{Mg}$. The thermal conductivity of $\mathrm{Mg}-\mathrm{TiB}_{2}$ nanocomposites decreased with an increase in the weight fraction of nano- $\mathrm{TiB}_{2}$.

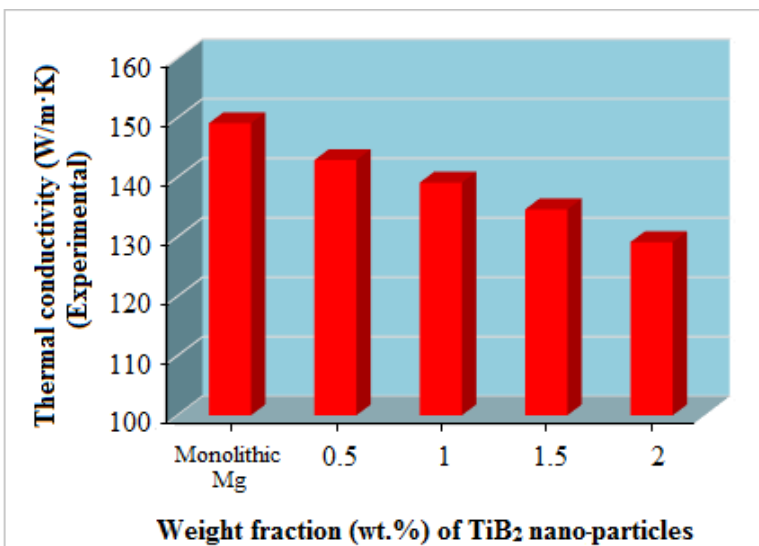

Figure 6. Thermal conductivities of monolithic $\mathrm{Mg}$ and $\mathrm{Mg}-\mathrm{TiB}_{2}$ nanocomposites

Compared to monolithic $\mathrm{Mg}$, the addition of $2 \mathrm{wt} . \%$ nano- $\mathrm{TiB}_{2}$ particles resulted in a $13 \%$ decrease in thermal conductivity of $\mathrm{Mg}-\mathrm{TiB}_{2}$ nanocomposite. Reduction of thermal conductivity of nano- $\mathrm{TiB}_{2}$ particle reinforced $\mathrm{Mg}$ matrix composites can simply be attributed to a lower thermal conductivity of $\mathrm{TiB}_{2}$ than that of $\mathrm{Mg}$. To be explained in detail, thermal conduction in MMCs that are reinforced with ceramic particles is more difficult than in monolithic metals because the heat is conducted only by phonons (lattice vibrations) in ceramics, whereas free electrons and phonons contribute to thermal conduction in the metal matrix, leading to a decrease in thermal conductivity in MMCs.

The thermal conductivity of $\mathrm{Mg}-\mathrm{TiB}_{2}$ nanocomposites declined at an increasing rate as seen in Figure 6.
Therefore, the reason for the reduction in thermal conductivity of $\mathrm{Mg}-\mathrm{TiB}_{2}$ nanocomposites may be attributed not only to the increase in the weight fraction of nano- $\mathrm{TiB}_{2}$ particles but also to the pores formed in the $\mathrm{Mg}-\mathrm{TiB}_{2}$ nanocomposites, because porosity has a negative effect on thermal conductivity [27]. Nanoparticles result in a higher level of porosity in MMNCs due to the high tendency of nano-particles to agglomerate. The porosity level of $\mathrm{Mg}^{-\mathrm{TiB}_{2}}$ nanocomposites raised with an increase in the weight fraction of nano- $\mathrm{TiB}_{2}$ particles (Table 2), which may have led to the decrease of thermal conductivity. In addition, the agglomeration of reinforcement particles may have contributed to the decline in thermal conductivity of $\mathrm{Mg}-\mathrm{TiB}_{2}$ nanocomposites because ceramic-particle agglomerates cause the electrons to scatter, reducing thermal conductivity.

Table 2. Experimental and theoretical densities and porosity percentages of monolithic $\mathrm{Mg}$ and $\mathrm{Mg}-\mathrm{TiB}_{2}$ nanocomposites

\begin{tabular}{lccc}
\hline $\begin{array}{l}\text { Weight fraction of } \\
\mathrm{TiB} \text { particles } \\
(\%)\end{array}$ & $\begin{array}{c}\text { Experimental } \\
\text { density } \\
\left(\mathrm{g} / \mathrm{cm}^{3}\right)\end{array}$ & $\begin{array}{c}\text { Theoretical } \\
\text { density } \\
\left(\mathrm{g} / \mathrm{cm}^{3}\right)\end{array}$ & $\begin{array}{c}\text { Porosity } \\
(\%)\end{array}$ \\
\hline Monolithic $\mathrm{Mg}$ & 1.73326 & 1.74000 & 0.38736 \\
0.5 & 1.73208 & 1.74524 & 0.75405 \\
1 & 1.72985 & 1.75076 & 1.19434 \\
1.5 & 1.73108 & 1.75628 & 1.43485 \\
2 & 1.72828 & 1.76152 & 1.88701 \\
\hline
\end{tabular}

To estimate the thermal conductivity of $\mathrm{Mg}-\mathrm{TiB}_{2}$ nanocomposites $\left(K_{c}\right)$ and to compare the experimental results obtained, the following analytical equation developed by Davis et al. (1995) was used [28]:

$K_{c}=K_{m} \frac{\left[K_{p}(1+2 \alpha)+2 K_{m}\right]+2 \Phi\left[K_{p}(1-\alpha)-K_{m}\right]}{\left[K_{p}(1+2 \alpha)+2 K_{m}\right]-\Phi\left[K_{p}(1-\alpha)-K_{m}\right]}$

$\alpha=\frac{R_{B d} K_{m}}{a}$

$R_{B d}=\frac{1}{h}$

where $K_{m}$ and $K_{p}$ are the thermal conductivities of the matrix and the reinforcement particle, respectively, $\Phi$ and $a$ are the volume fraction and the mean (average) of reinforcement particles, respectively, and $h$ is the coefficient of heat transfer at the matrix-particle interface.

Equation (4) ignores the effects of the pores, the reinforcement particle agglomerates, and the matrixparticle interface, and also assumes that the particles are uniformly distributed within the microstructure. Therefore, the following equation considering porosity was used to make a more reliable estimation of thermal conductivity of $\mathrm{Mg}-\mathrm{TiB}_{2}$ nanocomposites [29]:

$K_{m}=$
$\lambda_{p}\left(3 V_{s}-1\right)+\lambda_{s}\left(3 V_{p}-1\right)+\left\{\left[\lambda_{p}\left(3 V_{s}-1\right)+\lambda_{s}\left(3 V_{p}-1\right)\right]^{2}+8 \lambda_{p} \lambda_{s}\right\}^{1 / 2}$ 
where $\lambda_{p}$ and $\lambda_{s}$ are the thermal conductivities of the pore and the solid-structure, respectively, and $v_{p}$ and $v_{s}$ are the volume fractions of the pore and the solidstructure, respectively.

Figure 7 shows the thermal conductivity values obtained using Equations (4) and (5) that ignore and take into account porosity for $\mathrm{Mg}-\mathrm{TiB}_{2}$ nanocomposites. The predicted thermal conductivity using Equation (4) was higher than the estimated thermal conductivity using Equation (5). Furthermore, the analytical results obtained using Equations (4) and (5) for the thermal conductivity of $\mathrm{Mg}-\mathrm{TiB}_{2}$ nanocomposites were higher than the experimental results. (Figure 8). However, as shown in Figure 8, the predicted results using Equation (5) considering the pore effect were closer to the experimental results. Although Equation (5) took into account the pore effect, it estimated higher values than the experimental results (Figure 8). It can be attributed that, in addition to the pores and reinforcement particle agglomerates, the interface between the metal matrix and ceramic reinforcements is another factor that resists heat flow due to the scattering of phonons and electrons in this region. This can be particularly significant in nanoparticle reinforced composites because the total amount of interfaces of nano-particles is very high.

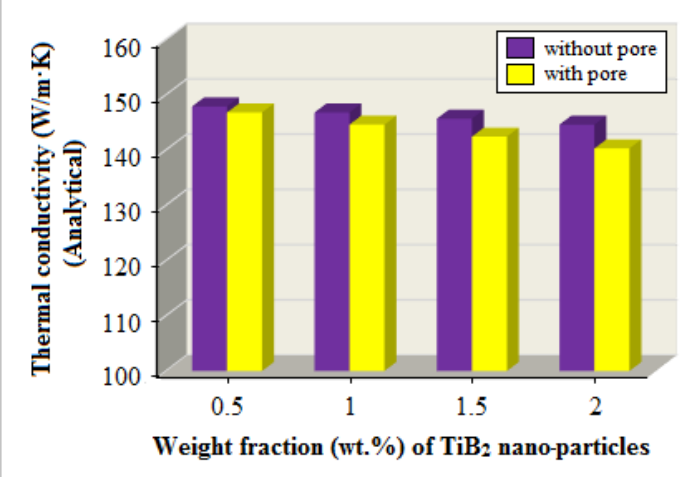

Figure 7. Prediction of thermal conductivities of $\mathrm{Mg}$ $\mathrm{TiB}_{2}$ nanocomposites using analytical equations with and without pore effect

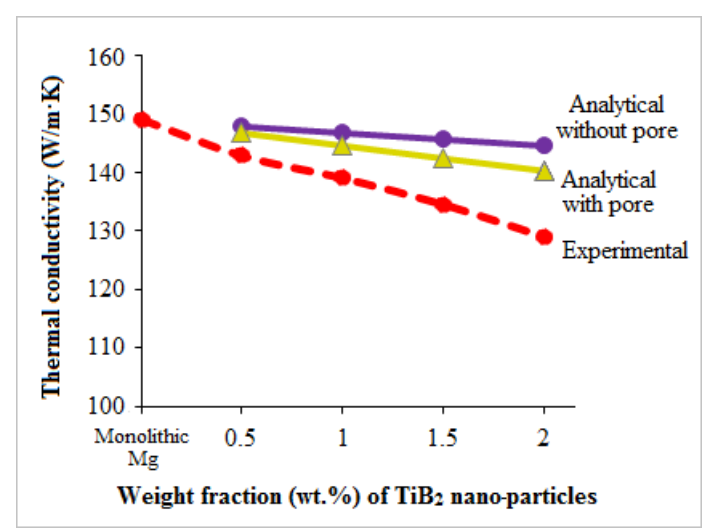

Figure 8. Comparison of experimental and analytically predicted thermal conductivities of $\mathrm{Mg}$ $\mathrm{TiB}_{2}$ nanocomposite

\subsection{Electrical Conductivity}

The experimental electrical conductivity of monolithic $\mathrm{Mg}$ and $\mathrm{Mg}-\mathrm{TiB}_{2}$ nanocomposites is shown in Figure 9. The electrical conductivities of $\mathrm{Mg}_{-} \mathrm{TiB}_{2}$ nanocomposites were lower than that of the monolithic $\mathrm{Mg}$. The electrical conductivity of $\mathrm{Mg}-\mathrm{TiB}_{2}$ nanocomposites decreased with an increase in the weight fraction of nano- $\mathrm{TiB}_{2}$ particles due to the poorer electrical conductivity of ceramic-based $\mathrm{TiB}_{2}$ particles. Compared to monolithic $\mathrm{Mg}$, the addition of $2 \mathrm{wt} \%$ $\mathrm{TiB}_{2}$ nano-particles resulted in a $29 \%$ decrease in the electrical conductivity of $\mathrm{Mg}-\mathrm{TiB}_{2}$ nanocomposite.

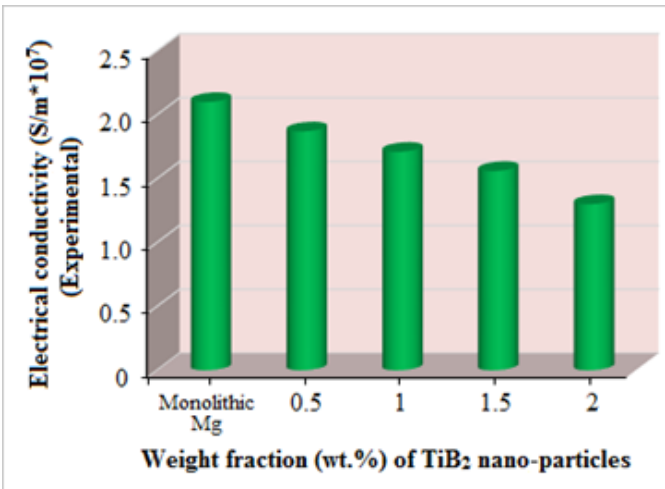

Figure 9. Electrical conductivity of monolithic $\mathrm{Mg}$ and $\mathrm{Mg}-\mathrm{TiB}_{2}$ nanocomposites

In addition to experimental findings, the electrical conductivity $\left(\psi_{c}\right)$ of $\mathrm{Mg}^{-\mathrm{TiB}_{2}}$ nanocomposites was predicted using the following analytical equation [30]:

$\psi_{c}=\frac{2 \psi_{m}\left(1-V_{r}\right)\left(1-\xi_{i}\right)}{V_{r}+2\left(1-\xi_{i}\right)}$

where $\psi_{m}$ is the electrical conductivity of the matrix, $V_{r}$ is the volume fraction of the reinforcement particles, and $\xi_{i}$ is the microstructural parameter. $\xi_{i}$ value for twophases (components) materials, such as particlereinforced metal matrix composites, can be calculated using numerical equations based (depending) on the microstructural arrangement and shape of the components, such as poly-dispersed hard spheres and simple cubic, bcc, and fcc arrangements of hard spheres. In this study, ceramic nano- $\mathrm{TiB}_{2}$ particles were assumed as poly-dispersed hard spheres, and $\xi_{i}$ value was taken equal to $0.5 \cdot V_{r}$ [30].

The electrical conductivity value predicted using Equation (6) was higher than experimental result of a constant weight fraction of nano- $\mathrm{TiB}_{2}$ particles for $\mathrm{Mg}$ $\mathrm{TiB}_{2}$ nanocomposites (Figure 10). The mechanism of electrical conductivity is identical to that of thermal conductivity. The reasons for this deviation between predicted and experimental results can therefore be attributed to the factors mentioned in the previous section. 


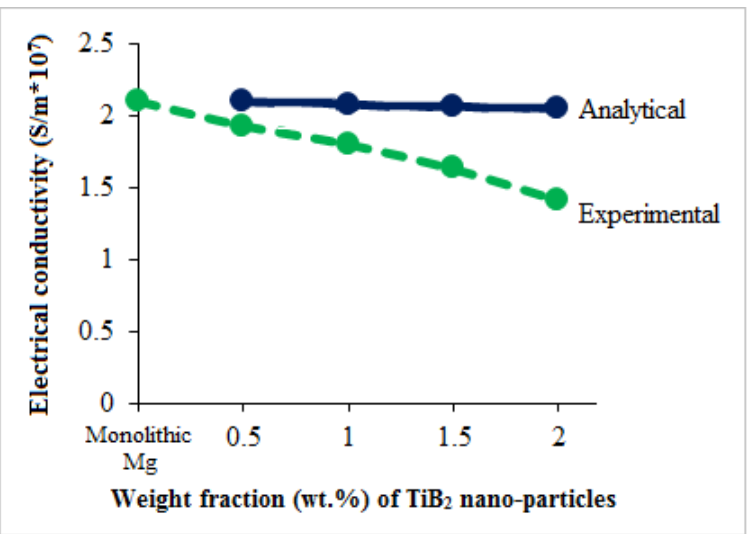

Figure 10. Comparison of experimental and analytically predicted electrical conductivities of $\mathrm{Mg}$ $\mathrm{TiB}_{2}$ nanocomposites

In conclusion, both electrical and thermal conductivities in $\mathrm{Mg}-\mathrm{TiB}_{2}$ nanocomposites were lower than in monolithic $\mathrm{Mg}$ and decreased as the weight fraction of nano- $\mathrm{TiB}_{2}$ particles increased. Although the equations developed to predict electrical and thermal conductivities take into account factors such as porosity that may affect electrical and thermal conductivity, they still predict slightly higher results than experimental results due to all the reasons described above, such as agglomeration of nano- $\mathrm{TiB}_{2}$ particles.

\subsection{Compressive Properties}

The compressive yield strength (CYS), ultimate compressive strength (UCS), and failure strain of monolithic $\mathrm{Mg}$ and $\mathrm{Mg}-\mathrm{TiB}_{2}$ nanocomposites are shown in Figures 11-13. Mg- $\mathrm{TiB}_{2}$ nanocomposites had higher CYS and UCS than monolithic Mg. The CYS and UCS of $\mathrm{Mg}-\mathrm{TiB}_{2}$ nanocomposites increased with an increase in the weight fractions of nano- $\mathrm{TiB}_{2}$. The addition of $1.5 \mathrm{wt} . \%$ nano- $\mathrm{TiB}_{2}$ particles led to increases of 30\% and 34\% in CYS and UCS, respectively. On the other hand, the CYS and UCS of ${\mathrm{Mg}-\mathrm{TiB}_{2}}_{2}$ nanocomposite with 2 wt.\% $\mathrm{TiB}_{2}$ nano-particles decreased. It can be attributed to the high number of pores and clusters of $\mathrm{TiB}_{2}$ particles in $\mathrm{Mg}-2 \mathrm{wt} . \% \mathrm{TiB}_{2}$ nanocomposites.

The enhanced strength of $\mathrm{Mg}-\mathrm{TiB}_{2}$ nanocomposites may have been resulted from not only the load-carrying capacity of nano- $\mathrm{TiB}_{2}$ particles but also from the inhibition of dislocation movement by nano- $\mathrm{TiB}_{2}$ particles, the reduction of grain size due to nano- $\mathrm{TiB}_{2}$ particles, and increasing the number of dislocations due to Orowan strengthening mechanism and thermal expansion coefficient mismatch of $\mathrm{Mg}$ matrix and nano-TiB 2 particles [21]. Nano-particles act as obstacles against to grain growth during sintering process. Also, the distance between nano-particles decreases with an increase in the amount of reinforcement particles [2]. Both the reinforcement particles themselves and the reduction in grain size inhibit the movement of the dislocations [31], which may have contributed to the improved CYS and UCS in $\mathrm{Mg}-\mathrm{TiB}_{2}$ nanocomposites.

The other mechanisms that led to an improvement in the strength of the $\mathrm{Mg}-\mathrm{TiB}_{2}$ nanocomposites could be the dislocation-based strengthening mechanisms such as Orowan and the thermal expansion coefficient mismatch between the $\mathrm{Mg}$ matrix and nano- $\mathrm{TiB}_{2}$ particles. Strengthening mechanism related to the mismatch of thermal expansion coefficients of metal matrix and ceramic nano-particles is controlled by geometrically necessary dislocations. According to the Taylor strengthening model [32], improving in the compressive strength of Mg-TiB2 nanocomposites due to dislocation enrichment induced by thermal mismatch between the constituents may have increased due to increase in the amount of the nano- $\mathrm{TiB}_{2}$ particles and the differences in the thermal expansion coefficients of the $\mathrm{Mg}$ matrix and nano- $\mathrm{TiB}_{2}$ particles and in the test and sintering temperatures. The Orowan strengthening mechanism is considered to be another effective mechanism for enhancing the strength of nano-particle reinforced composites. In this mechanism, nano-sized reinforcement particles impede the dislocations and promote dislocations bowing around the particles, which raise the number of dislocations, leading to an increase in strength of the nano-particle reinforced composites. The effect of Orowan strengthening mechanism increases as the amount of nano-particles increases. As a result, compared to monolithic $\mathrm{Mg}$, the Orowan mechanism may have contributed to an increase in the compressive strength of $\mathrm{Mg}-\mathrm{TiB}_{2}$ nanocomposites with an increase in the weight fraction of nano- $\mathrm{TiB}_{2}$ particles.

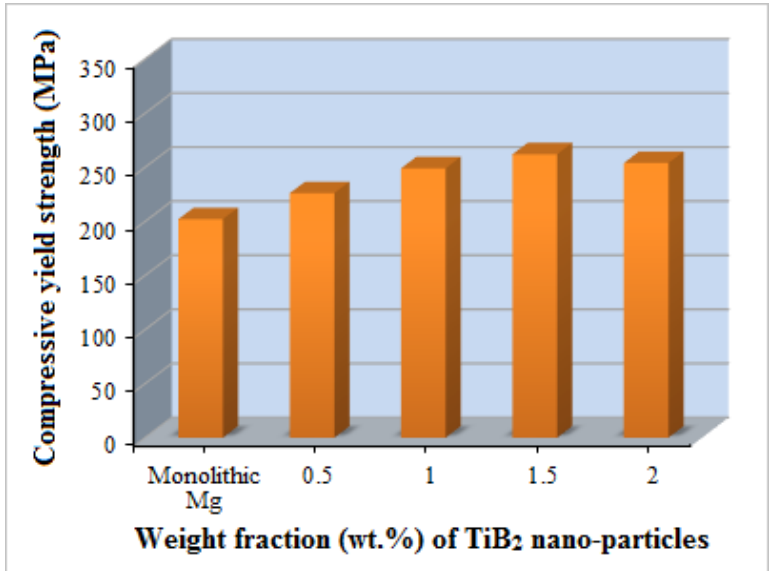

Figure 11. Compressive yield strengths of monolithic $\mathrm{Mg}$ and $\mathrm{Mg}-\mathrm{TiB}_{2}$ nanocomposites 


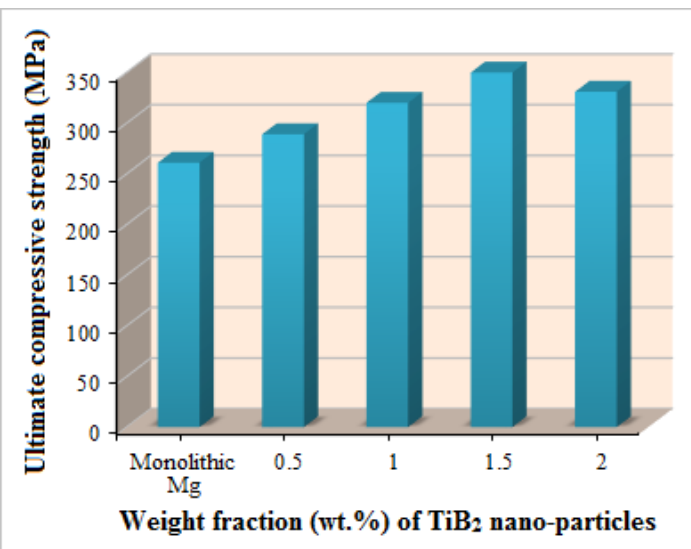

Figure 12. Ultimate compressive strengths of monolithic $\mathrm{Mg}$ and $\mathrm{Mg}-\mathrm{TiB}_{2}$ nanocomposites

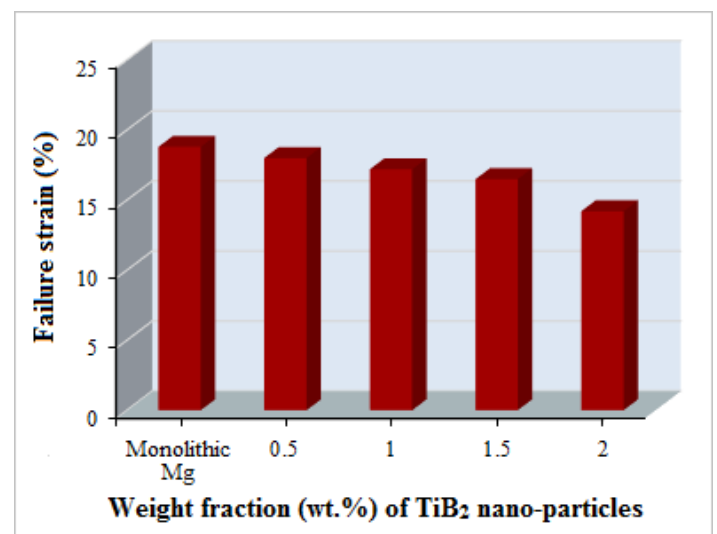

Figure 13. Failure strains of monolithic $\mathrm{Mg}$ and $\mathrm{Mg}$ $\mathrm{TiB}_{2}$ nanocomposites

It should be noted that the strengthening mechanisms described above are effective when the nano-particles are uniformly distributed in the microstructure; on the other hand, nano-particles are highly probable to agglomerate and cluster, which may cause the reinforcement particles and strengthening mechanisms to be ineffective. These regions cause a deterioration in the strength of the composite due to early crack initiation and/or rapid crack propagation; also, due to the loose bonding of the particles, the reinforcement particles are ineffective in these regions [33], and the strengthening mechanisms are ineffective in these regions due to loose bonding of particles. In addition to the negative impact of the particle cluster, the pores formed in the microstructure can have a negative effect on the mechanical properties of particle-reinforced metal matrix composites [34]. Although porosity formation is inevitable in particle-reinforced composites, these composites have superior mechanical properties than unreinforced metals. This implies that the beneficial effect of reinforcement particles on strength improvement surpasses the negative influence of porosity. For this reason, although the porosity level increased with increasing the amount of nano- $\mathrm{TiB}_{2}$ particles in this study, the CYS and UCS of Mg-TiB nanocomposites could be improved by up to $1.5 \mathrm{wt} . \%$ of nano- $\mathrm{TiB}_{2}$ particles (Figures 11 and 12), indicating that the strengthening effect of nano- $\mathrm{TiB}_{2}$ particles was more effective than the negative impact of porosity. However, it should be noted that the amount of pores and clusters increases as the weight or volume fractions of the reinforcement particles, and after reaching a threshold (critical) amount of reinforcement particles, the number and size of pores and particle clusters increase to the level where their negative impact on material strength becomes more pronounced [35]. As a result, in this study, the weight fraction of $2 \mathrm{wt}$.\% nano$\mathrm{TiB}_{2}$ particles had a negative impact on the CYS and UCS of $\mathrm{Mg}-\mathrm{TiB}_{2}$ nanocomposite in this study (Figures 11 and 12) due to high amount of porosity and particle cluster (Table 2, Figures 4, 14(b) and (c)), resulting in a decrease in the CYS and UCS of $\mathrm{Mg}^{-\mathrm{TiB}_{2}}$ nanocomposite.

While the UCS of $\mathrm{Mg}-\mathrm{TiB}_{2}$ nanocomposite with $1.5 \mathrm{wt} \%$ nano- $\mathrm{TiB}_{2}$ particles improved by $34 \%$ (Figure 12 ), the failure strain of this composite decreased by $12 \%$ compared to monolithic Mg (Figure 13). As the amount of nano- $\mathrm{TiB}_{2}$ particles increased, the failure strain of $\mathrm{Mg}-\mathrm{TiB}_{2}$ nanocomposites decreased. Monolithic $\mathrm{Mg}$ had a more ductile fracture than $\mathrm{Mg}$ $\mathrm{TiB}_{2}$ nanocomposite as seen in Figure 14. On the other hand, the number and size of agglomeration areas and clusters of nano- $\mathrm{TiB}_{2}$ particles in the $\mathrm{Mg}^{-\mathrm{TiB}_{2}}$ nanocomposite with $2 \mathrm{wt} \%$ nano- $\mathrm{TiB}_{2}$ particles was very high (Figure 14(b) and (c)), which may have led to a reduction in its failure strain.
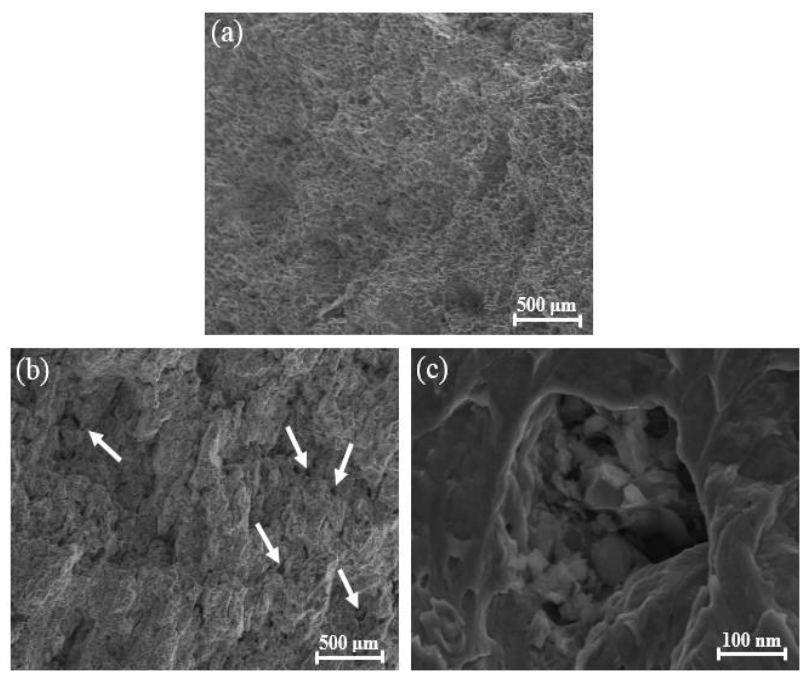

Figure 14. SEM images of the fracture surfaces of (a) monolithic $\mathrm{Mg}$, (b) $\mathrm{Mg}-2 \mathrm{wt} . \% \mathrm{TiB}_{2}$ nanocomposite (white arrows indicate clusters of nano- $\mathrm{TiB}_{2}$ particles), and (c) a cluster of nano- $\mathrm{TiB}_{2}$ particles in $\mathrm{Mg}-\mathrm{TiB}_{2}$ nanocomposite

\section{CONCLUSIONS}

The effects of nano- $\mathrm{TiB}_{2}$ particles on the electrical, thermal, and mechanical properties of $\mathrm{Mg}-\mathrm{TiB}_{2}$ nanocomposites produced using spark plasma sintering method were analytically and experimentally studied, 
and the results of this study can be summarized as follows:

- The thermal conductivities of $\mathrm{Mg}-\mathrm{TiB}_{2}$ nanocomposites were lower than that of monolithic $\mathrm{Mg}$, both analytically and experimentally, and decreased as the weight fraction of nano- $\mathrm{TiB}_{2}$ particles increased, due to a higher thermal resistance of nano- $\mathrm{TiB}_{2}$ particles and the interface between $\mathrm{Mg}$ matrix and nano- $\mathrm{TiB}_{2}$ particles, as well as increases in the amount and size of pores and agglomeration and clusters of nano- $\mathrm{TiB}_{2}$ particles. Analytical calculations yielded higher values than experimental results for the thermal conductivity of $\mathrm{Mg}-\mathrm{TiB}_{2}$ nanocomposites. The results obtained with the analytical equation considering the influence of the pore were closer to the experimental results.

- Similar to thermal conductivity, the experimental results of electrical conductivity were lower than the analytical results, and the electrical conductivities of the $\mathrm{Mg}-\mathrm{TiB}_{2}$ nanocomposites were lower than the monolithic $\mathrm{Mg}$ and decreased as the weight fraction of the nano- $\mathrm{TiB}_{2}$ particles increased. On the other hand, the reduction in electrical conductivity was higher than the decrease in thermal conductivity.

- Mg-TiB 2 nanocomposites had higher compressive yield strength and ultimate compressive strength than monolithic $\mathrm{Mg}$ and increased by $30 \%$ and $34 \%$, respectively. On the other hand, the compressive strength of $\mathrm{Mg}-\mathrm{TiB}_{2}$ nanocomposite reduced by a higher weight fraction $(>1.5 \mathrm{wt} . \%)$ of nano- $\mathrm{TiB}_{2}$ particles due to the increase in the amount of pores and the agglomeration of nano- $\mathrm{TiB}_{2}$ particles. The compressive strength of $\mathrm{Mg}-\mathrm{TiB}_{2}$ nanocomposite with 1.5 wt. $\%$ nano- $\mathrm{TiB}_{2}$ particles improved by $34 \%$; on the other hand, its failure strain decreased by $12 \%$ compared to monolithic $\mathrm{Mg}$.

\section{REFERENCES}

[1] Akbari, M.K., Shirvanimoghaddam, K., Hai, Z., Zhuiykov, S. and Khayyam, H. (2017). Al-TiB 2 micro/nanocomposites: Particle capture investigations, strengthening mechanisms and mathematical modelling of mechanical properties. Mater. Sci. Eng. A, 682, 98-106.

[2] Malaki, M., Xu, W., Kasar, A.K., Menezes, P.L., Dieringa, H., Varma, R.S. and Gupta, M. (2019). Advanced metal matrix nanocomposites. Metals, 9(3), 330, 1-39.

[3] Ceschini, L., Dahle, A., Gupta, M., Jarfors, A.E.W., Jayalakshmi, S., Morri, A., Rotundo, F., Toschi, S. and Singh, R.A. (2017). Aluminum and magnesium metal matrix nanocomposites. Springer Nature, Singapore, pp. 1-164.

[4] Stalin, B., Ravichandran, M., Mohanavel, V. and Raj, L.P. (2020). Investigations into microstructure and mechanical properties of $\mathrm{Mg}$ 5 wt. $\% \mathrm{Cu}-\mathrm{TiB}_{2}$ composites produced via powder metallurgy route. J. Min. Metall. Sect. B: Metall., 56(1), 99-108.

[5] Abbas, A., Rajagopal, V. and Huang, S.J. (2021). Magnesium metal matrix composites and their applications. In: Magnesium alloys structure and properties, T.A. Tański, P. Jarka (eds.), IntechOpen, London, UK, 1-17.

[6] Shu, S., Yang, H., Tong, C. and Qiu, F. (2016). Fabrication of $\mathrm{TiC}_{\mathrm{x}}-\mathrm{TiB}_{2} / \mathrm{Al}$ composites for application as a heat sink. Materials, 9(642), 110.

[7] Rudajevová, A. and Lukáč, P. (2000). Thermal conductivity of $\mathrm{SiC}$ reinforced magnesium matrix composites. In: Microstructural investigation and analysis, B. Jouffrey (ed.), Wiley-VCH Verlag GmbH, Weinheim, Germany, pp. 179-183.

[8] Dieringa, H. (2020). Production and properties of light metal matrix nanocomposites. Metals, 10(1), 95, 1-4.

[9] Grasso, S., Sakka, Y. and Maizza, G. (2009). Electric current activated/assisted sintering (ECAS): a review of patents 1906-2008. Sci. Technol. Advanced Materials, 10(5), 053001, 124.

[10] Munir, Z. A., Tamburini, U. A. and Ohyanagi, M. (2006). The effect of electric field and pressure on the synthesis and consolidation of materials: a review of the spark plasma sintering method. $J$. Mater. Sci., 41(3), 763-777.

[11] Guillon, O., Gonzalez-Julian, J., Dargatz, B., Kessel, T., Schierning, G. and Räthel, J. (2014). Field-assisted sintering technology/spark plasma sintering: mechanisms, materials, and technology developments. Adv. Eng. Mater., 16(7), 830-849.

[12] Sharma, N., Alam, S.N. and Ray, B.C. (2019). Fundamentals of spark plasma sintering (SPS): An ideal processing technique for fabrication of metal matrix nanocomposites. In: Spark plasma sintering of materials: Advances in processing and applications, C. Pasquale (ed.), Springer International Publishing, Cham, Switzerland, 219, pp. 21-59.

[13] Muhammad, W.N.A.W., Mutoh, Y. and Miyashita, Y. (2010). Microstructure and mechanical properties of magnesium prepared by spark plasma sintering. Adv. Mat. Res., 129-131, 764-768.

[14] Mondet, M, Barraud, E., Lemonnier, S., Guyon, J., Allain, N. and Grosdidier, T. (2016). Microstructure and mechanical properties of AZ91 magnesium alloy developed by spark plasma sintering. Acta Mater., 119, 55-67. 
[15] Dey, A.and Pandey, K.M., (2015). Magnesium metal matrix composites-A review, Rev. $A d v$. Mater. Sci., 42, 58-67.

[16] Muhammad, W.N.A.W., Sajuri, Z., Mutoh, Y.and Miyashita, Y., (2011). Microstructure and mechanical properties of magnesium composites prepared by spark plasma sintering technology. $J$. Alloy. Compd., 509, 6021-6029, 2011.

[17] Garbiec, D. (2016). Study on microstructure and some mechanical properties of spark plasma sintered $\mathrm{Mg}-\mathrm{Al}_{2} \mathrm{O}_{3}$ composites. The 5 International Lower Silesia-Saxony Conference: Advanced Metal Forming Processes in Automotive Industry, Wroclaw, Poland, 28-29 June.

[18] Ghasali, E., Alizadeh, M., Niazmand, M. and Ebadzadeh, T. (2017). Fabrication of magnesiumboron carbide metal matrix composite by powder metallurgy route: Comparison between microwave and spark plasma sintering. J. Alloys Compd., 697, 200-207.

[19] Zhang, H., Zhao, Y., Yan, Y., Fan, J., Wang, L., Dong, H. and Xu, B. (2017). Microstructure evolution and mechanical properties of $\mathrm{Mg}$ matrix composites reinforced with $\mathrm{Al}$ and nano $\mathrm{SiC}$ particles using spark plasma sintering followed by hot extrusion. J. Alloys Compd., 725, 652-664.

[20] Dieringa, H. (2013). Applications: magnesiumbased metal matrix composites (MMCs). In: Fundamentals of magnesium alloy metallurgy, M.O. Pekguleryuz, K.A. Kainer, A.A. Kaya (eds.), Woodhead Publishing, Cambridge, UK, pp. 317-341.

[21] Xiao, P., Gao, Y., Yang, C., Liu, Z., Li, Y. and $\mathrm{Xu}$, F. (2018). Microstructure, mechanical properties and strengthening mechanisms of $\mathrm{Mg}$ matrix composites reinforced with in situ nanosized $\mathrm{TiB}_{2}$ particles, Mater. Sci. Eng. A., 710, 251-259.

[22] Aydin, F. and Sun, Y. (2018). Investigation of wear behaviour and microstructure of hot-pressed $\mathrm{TiB}_{2}$ particulate-reinforced magnesium matrix composites. Can. Metall. Q., 57(4), 455-469.

[23] Jiang, Q.C., Wang, H.Y., Ma, B.X., Wang, Y. and Zhao, F. (2004). Fabrication of $\mathrm{TiB}_{2}$ particulate reinforced magnesium matrix composites by powder metallurgy. Mater. Lett., 58(27-28), 3509-3513.

[24] Leich, L., Röttger, A., Kuchenbecker, R. and Theisen, W. (2020). Electro-discharge sintering of nanocrystalline $\mathrm{NdFeB}$ magnets: process parameters, microstructure, and the resulting magnetic properties. J. Mater. Sci.: Mater. Electron., 31, 20431-20443.

[25] Balice, L., Cologna, M., Audubert, F. and Hazemann, J.L. (2021). Densification mechanisms of $\mathrm{UO}_{2}$ consolidated by spark plasma sintering. J. Eur. Ceram. Soc., 41(1), 719-728.

[26] Schmidt, R., Martin Scholze, H. and Stolle, A. (2016). Temperature progression in a mixer ball mill. Int. J. Ind. Chem., 7, 181-186.

[27] Calin, R., Pul, M. and Pehlivanli, Z.O., (2012). The effect of reinforcement volume ratio on porosity and thermal conductivity in $\mathrm{Al}-\mathrm{MgO}$ composites. Mater. Res., 15(6), 1057-1063.

[28] Davis, L.C. and Artz, B.E. (1995). Thermal conductivity of metal-matrix composites. J. Appl. Phys., 77(10), 4954-4960.

[29] Ast, D.G. (1974). Evidence for percolationcontrolled conductivity in amorphous $\mathrm{As}_{\mathrm{x}} \mathrm{Te}_{1-\mathrm{x}}$ films. Phys. Rev. Lett., 33(17), 1042-1045.

[30] Weber, L., Dorn, J. and Mortensen, A. (2003). On the electrical conductivity of metal matrix composites containing high volume fractions of non-conducting inclusions. Acta Mater., 51, 3199-3211.

[31] Beni, H.A., Alizadeh, M., Ghaffari, M. and Amini, R. (2014). Investigation of grain refinement in $\mathrm{Al} / \mathrm{Al}_{2} \mathrm{O}_{3} / \mathrm{B}_{4} \mathrm{C}$ nano-composite produced by ARB. Compos. B. Eng., 58, 438-442, 2014.

[32] Miller, W.S. and Humphreys, F.J. (1991). Strengthening mechanisms in particulate metal matrix composites. Scr. Mater., 25(1), 33-38.

[33] Iqbal, A.K.M.A., Arai, Y. and Araki, W. (2013). Effect of hybrid reinforcement on crack initiation and early propagation mechanisms in cast metal matrix composites during low cycle fatigue. Mater. Des., 45, 241-252.

[34] Manohar, G., Pandey, K.M. and Maity, S.R. (2021). Effect of sintering mechanisms on mechanical properties of AA7075/B ${ }_{4} \mathrm{C}$ composite fabricated by powder metallurgy techniques. Ceram. Int., 47(11), 15147-15154.

[35] Senthilkumar, P., Manimaran, R. and Y.K., Reddy. (2021). Evaluation of mechanical properties of hybrid Al7009 nanocomposite. Energy Sources A: Recovery Util. Environ. Eff., 43(2), 216-224. 